\title{
Dp71 gene disruption alters the composition of the dystrophin-associated protein complex and neuronal nitric oxide synthase expression in the hypothalamic supraoptic and paraventricular nuclei
}

\author{
Roza Benabdesselam ${ }^{1,2}$, Latifa Dorbani-Mamine ${ }^{2}$, Ouahiba Benmessaoud-Mesbah², Alvaro Rendon ${ }^{3}$, \\ Sakina Mhaouty-Kodja ${ }^{4,5,6}$ and Hélène Hardin-Pouzet ${ }^{4,5,6}$ \\ ${ }^{1}$ Unité de Recherches, Faculté des Sciences Biologiques/UMMTO, BP 17, Tizi-Ouzou, Algeria \\ ${ }^{2}$ Laboratoire de Neurochimie/LBPO, FSB/USTHB, BP 32, El Alia, Bab Ezzouar, Alger, Algeria \\ ${ }^{3}$ INSERM UMRS-592, Laboratoire de Physiopathologie Cellulaire et Moléculaire de la Rétine, Institut de la Vision, Paris, France \\ ${ }^{4}$ UPMC University Paris 06, 7 Quai Saint Bernard, F-75 005 Paris, France \\ ${ }^{5}$ INSERM U952, F-75005 Paris, France \\ ${ }^{6}$ CNRS UMR 7224, F-75005 Paris, France \\ (Correspondence should be addressed to $\mathrm{H}$ Hardin-Pouzet who is now at Physiopathologie des Maladies du Système Nerveux Central, INSERM UMRS 952, \\ CNRS UMR 7224, UPMC, 7 Quai Saint Bernard, Bât A, 3ème étage, 75252 Paris Cedex 05, France; Email: helene.pouzet@snv.jussieu.fr)
}

\begin{abstract}
DP71 is the major cerebral dystrophin isoform and exerts its multiple functions via the dystrophin-associated protein complex (DAPC), also comprised of $\beta$-dystroglycan ( $\beta-\mathrm{DG})$ and $\alpha 1$-syntrophin ( $\alpha 1-\mathrm{Syn})$. Since DP71 disruption leads to impairment in the central control of the osmoregulatory axis, we investigated: 1) the DAPC composition in the hypothalamic supraoptic nucleus (SON) and paraventricular nucleus (PVN) of Dp71-null mice; and 2) the expression and activity of neuronal nitric oxide synthase (nNOS), because it is a potential partner of the DAPC and a functional index of osmoregulatory axis activity. In wild-type mice, dystrophins and their autosomal homologs the utrophins, $\beta-D G$, and $\alpha 1-S y n$ were localized in astrocyte end feet. In Dp71-null mice, the levels of $\beta$-DG and $\alpha 1$-Syn were lower and utrophin expression did not change. The location of the
\end{abstract}

DAPC in astrocytic end feet suggests that it could be involved in hypothalamic osmosensitivity, which adapts the osmotic response. The altered composition of the DAPC in Dp71-null mice could thus explain why these mice manifest an hypoosmolar status. In the SON and PVN neurons of Dp71-null mice, nNOS expression and activity were increased. Although we previously established that DP140 is expressed de novo in these neurons, the DAPC remained incomplete due to the low levels of $\beta$-DG and $\alpha 1$-Syn produced in these cells. Our data reveal the importance of DP71 for the constitution of a functional DAPC in the hypothalamus. Such DAPC disorganization may lead to modification of the microenvironment of the SON and PVN neurons and thus may result in a perturbed osmoregulation.

Journal of Endocrinology (2012) 213, 239-249

\section{Introduction}

DP71 is the major cerebral isoform of the Duchenne muscular dystrophy $(D M D)$ gene, which is known to code for several dystrophin proteins. Its full-length product is a $427 \mathrm{kDa}$ protein (DP427) composed of an N-terminal actinbinding domain, a central region of spectrin-like repeats, and a cysteine-rich C-terminal domain (Koenig et al. 1988). This C-terminal domain allows dystrophin to form a dystrophinassociated protein complex (DAPC) with a group of extracellular, integral membrane and cytoplasmic proteins (Suzuki et al. 1994, Lapidos et al. 2004).

Analysis of the $D M D$ gene structure revealed the presence of internal promoters that lead to the generation of short
C-terminal DMD products. We previously demonstrated that DP71 knockout mice exhibit a perturbed osmosregulatory axis characterized by a lower osmostat set point and low plasma osmolality under normal conditions, but with a normal response to hyperosmolality (Benabdesselam et al. 2010). Osmoregulation is controlled by the CNS via the hypothalamo-neurohypophyseal complex that contains the magnocellular neurons of the supraoptic nucleus $(\mathrm{SON})$ and the paraventricular nucleus (PVN). These neurons send their axons toward the neurohypophysis and release the antidiuretic hormone vasopressin (arginine vasopressin (AVP)) into the blood stream (Antunes-Rodrigues et al. 2004). In Dp71-null mice, we described compensatory ectopic expression of DP140 in the magnocellular neurons of the hypothalamus. 
To more fully understand the mechanisms underlying the low osmolality caused by the lack of DP71, we analyzed the composition of the DAPC complex in Dp71-null mice.

The DAPC includes several distinct subcomplexes, which depend on the dystrophin isoform controlling its assembly. In the CNS, the DP71-associated DAPC is assembled through interactions among dystroglycan, $\alpha 1$-syntrophin ( $\alpha 1-$ Syn), and neuronal nitric oxide synthase (nNOS; Tadayoni et al. 2012). Dystroglycan is a heterodimeric glycoprotein subcomplex located on the surfaces of cells in most adult tissues (Michele \& Campbell 2003) and consists of a transmembrane $\beta$ subunit and a noncovalently associated extracellular $\alpha$ subunit. The extracellular domain interacts with extracellular matrix proteins, such as laminins, agrin, and perlecan, whereas the cytoplasmic domain ( $\beta$-dystroglycan $(\beta-D G))$ possesses signaling motifs and is linked to the actin cytoskeleton via dystrophin (Winder 2001, Michele \& Campbell 2003). Syntrophins (SYNs) are a multigene family of proteins, including $\alpha 1, \beta 1, \beta 2, \gamma 1$, and $\gamma 2$ SYN, in which each member features a postsynaptic density-95/ disc large/zonula occludens-1 (PDZ) domain (Adams et al. 2000, Piluso et al. 2000). Many proteins have been identified as SYN-PDZ domain ligands, including nNOS (Brenman et al. 1996, Zhou \& Zhu 2009). The importance of Syn-ligand interactions was demonstrated in skeletal muscle, where the $\alpha$-Syn-PDZ domain is required to localize nNOS to the sarcolemma (Adams et al. 2000). Disruption of the dystrophin/ $\alpha$-Syn/nNOS complex results in failure of skeletal muscle contraction (Thomas et al. 1998, 2003, Lai et al. 2009).

Dystrophins have autosomal homologs designated as dystrophin-related proteins (Ohlendieck et al. 1993). Among them, utrophins are more widely expressed than dystrophins, as they are found not only in muscle but also in other cell types, such as vascular endothelia (Matsumura et al. 1993) and retinal glial cells (Claudepierre et al. 1999). The structural and binding partner similarities between utrophin and dystrophin (Tinsley et al. 1992, Kramarcy et al. 1994, Winder et al. 1995, Blake et al. 2002) have raised the possibility that the two proteins are functionally redundant. Indeed, in sarcolemma and retina, utrophin can functionally compensate for the absence of dystrophin (Matsumura et al. 1992, Porter et al. 1998, Rybakova et al. 2002, Dalloz et al. 2003).

In the present study, we investigated the consequences of DP71 disruption on the composition of the DAPC complex (i.e. $\beta-\mathrm{DG}, \alpha 1-\mathrm{Syn}$, and utrophins) in the SON and the PVN of the Dp71-null hypothalamus. We also analyzed nNOS expression, because this protein potentially interacts with the DAPC and because it represents an index of osmoregulatory axis activation (Kadekaro 2004). Indeed, in the hypothalamoneurohypophysis complex, NO is an important modulator of vasopressin synthesis and secretion (Yuan et al. 2006, Raison et al. 2011, St-Louis et al. 2012). nNOS and NADPH diaphorase, the histochemical marker of NOS activity, are both present in magnocellular neurons (Grange-Messent $e t$ al. 2004, Kadekaro 2004, Maolood et al. 2007). Their expression levels and activity increase when magnocellular neuron activity increases in response to osmotic stimulation, dehydration, or hypovolemia (Kadowaki et al. 1994, Villar et al. 1994, Ueta et al. 1995, 1998).

\section{Materials and Methods}

\section{Animals}

All experiments were performed in accordance with French and European legal requirements (decree 87-848, 86/609/ECC).

Six-week-old male Balb/c mice (supplied by Janvier, Le Genest Saint Isle, France) and Dp71-null mice (Sarig et al. 1999) were housed in $1200 \mathrm{~h}$ light: $1200 \mathrm{~h}$ darkness conditions and provided with food and water ad libitum. Groups of three animals were used for immunohistochemistry (IHC) and NADPH-diaphorase histochemistry and groups of six to ten animals were used for western blotting experiments. All experiments were repeated three to five times.

\section{Electrophoresis and immunoblotting}

After anesthesia, brains were removed, and $400 \mu \mathrm{m}$ frontal sections of the hypothalamus area were cut with a vibroslice. The SON and PVN were punched out and homogenized in a buffer containing $50 \mathrm{mM}$ Tris- $\mathrm{HCl}(\mathrm{pH} 7 \cdot 2), 150 \mathrm{mM} \mathrm{NaCl}$, $0 \cdot 1 \%$ SDS, $0 \cdot 01 \%$ sodium deoxycholate, and $1 \%$ Protease Inhibitor Cocktail (Sigma). Each sample was denatured in $2 \times$ Laemmli buffer $\left(5 \mathrm{~min}\right.$ at $95^{\circ} \mathrm{C}$; Sigma). Twenty micrograms of protein were subjected to electrophoresis $(150 \mathrm{~V})$ on NuPAGE 4-12\% Bis-Tris Gels (Invitrogen) in MOPS-SDS running buffer and the resolved proteins were electrotransferred $\left(400 \mathrm{~mA}, 4{ }^{\circ} \mathrm{C}, 2 \mathrm{~h}\right)$ onto a PVDF membrane (Sigma). Blots were blocked with a solution of $5 \%$ nonfat milk powder (Bio-Rad) and $0 \cdot 1 \%$ Tween $20(1 \mathrm{~h})$ in PBS, and incubated overnight at $4{ }^{\circ} \mathrm{C}$ with polyclonal rabbit antibodies against utrophins (1:200; Royuela et al. 2003), $\beta$-DG (1:400; Rivier et al. 1999), $\alpha 1-$ Syn (1:500; SigmaAldrich), or with mouse monoclonal antibodies against nNOS (1:400; Sigma-Aldrich) or $\beta$-actin (1:7500; Chemicon, Molsheim, France) diluted in the blocking solution. Primary antibody binding was detected by incubating the blots with HRP-conjugated anti-rabbit or anti-mouse secondary antibodies (1:5000; Interchim, Montluçon, France) and then developing the blots with the ECL Plus detection system (GE Healthcare, Hertfordshire, UK) and Kodak Biomax Light 1 film. The amounts of individual blotted proteins were estimated arbitrarily using TotalLab TL120 Software (Nonlinear, Inc., Long Beach, CA, USA). The value assigned to each band corresponds to the integration of its surface with its optical density. Band value was normalized to the value obtained for the corresponding actin band.

\section{Protein assays}

Protein concentrations were determined using the Coomassie Plus Protein assay kit (Pierce, Illkirch, France) according to the manufacturer's instructions. 


\section{Immunohistochemistry}

Mice were anesthetized (pentobarbital $25 \mathrm{mg} / \mathrm{kg}$ ) and perfused with $4 \%$ paraformaldehyde in $0 \cdot 1 \mathrm{M}$ phosphate buffer (PB). Frozen brains were sectioned $(20 \mu \mathrm{m}$, Leica, Le Pecq, France, CM300). Sections were blocked in 0.05 M PBS (pH 7•4), 1\% BSA, and 0.2\% Triton X-100 (1 h) and incubated overnight with one of the primary antibodies used for western blotting (anti-utrophin, $\beta-D G,-\alpha 1-S y n$, or -nNOS), either alone or combined with antibodies against AVP (1:5000; Robert et al. 1985), glial fibrillary acidic protein (GFAP; 1:200; Sigma), CD31/PECAM-1 (1:400; BD Biosciences Pharmingen, Le Pont de Claix, France), or dystrophin (Royuela et al. 2003) diluted in PBS/BSA/Triton buffer. Antigen-antibody complexes were revealed using a combination of Alexa 488-conjugated anti-rabbit IgG antibody (1:400; Invitrogen) and Alexa 594-conjugated anti-mouse IgG antibody (1:400; Invitrogen). Fluorescence was observed with a Zeiss microscope.

\section{NADPH-diaphorase staining}

NADPH-diaphorase staining was performed as described previously (Scherer-Singler et al. 1983). Briefly, slidemounted sections were incubated with $1 \mathrm{mM}$ NAPDH, $0 \cdot 2 \mathrm{mM}$ nitroblue tetrazolium, $0 \cdot 1 \mathrm{M}$ Tris- $\mathrm{HCl}(\mathrm{pH} 7 \cdot 2)$, and $0 \cdot 2 \%$ Triton $\mathrm{X}-100$ for $1 \mathrm{~h}$ at $37^{\circ} \mathrm{C}$. Sections were observed with a Zeiss microscope.

\section{Quantification}

All quantification steps were performed with Image $1.36 \mathrm{~b}$ Software (NIH, USA). The differences between Dp71-null mice and their controls were assessed by comparing the integrated density of the fluorescent signal on thresholded sections. For each section, the integrated fluorescence density level quantifies the sum of the values of the pixels within a predefined-size contour positioned in a reproducible manner. The fluorescence value for each animal is the sum of the measurements on five sections homogeneously distributed through the SON and the PVN.

\section{Statistical analysis}

Data were expressed as means \pm s.E.M. and compared in a oneway ANOVA, followed by Scheffe's test. Differences were considered statistically significant if $P<0 \cdot 05$.

\section{Results}

Levels of utrophins, $\beta-D G$, and $\alpha 1-S y n$ in the SON and PVN of Dp71-null mice

SON and PVN protein extracts from wild-type and Dp71null mice were analyzed by western blotting using antibodies directed against utrophins, $\beta-\mathrm{DG}$, or $\alpha 1-$ Syn to detect the presence of different components of the DAPC in the hypothalami of Dp71-null mice.

In the SON and PVN extracts, the utrophin antibody recognized four different isoforms of utrophin, Up400, Up260, Up140, and Up116/G, which migrated at 400, 260, 140 , and $116 \mathrm{kDa}$ respectively (Royuela et al. 2003; Fig. 1A and D). The absence of DP71 did not affect the levels of utrophin proteins detected in the SON and the PVN (Table 1).

We detected $\beta-\mathrm{DG}$ as a $43 \mathrm{kDa}$ band (Sgambato \& Brancaccio 2005) in the SON and PVN of wild-type mice (Fig. 1B and E). The levels of this protein in the SON and PVN were significantly lower in Dp71-null mice than in wild-type mice (Table 1).

We detected $\alpha 1-$ Syn as a single band of $59 \mathrm{kDa}$ (Tinsley et al. 1994) in the SON and PVN of wild-type mice (Fig. 1C and F). Like $\beta$-DG, the levels of this protein in both the SON and PVN were lower in Dp71-null mice than in wild-type mice (Table 1).

Taken together, and in view of our previous findings (Benabdesselam et al. 2010), our results indicate that utrophins, DP140, $\beta$-DG, and $\alpha 1-$ Syn are all present in the hypothalamus in the absence of DP71.

\section{Cellular location of utrophins, $\beta-D G$, and $\alpha 1-S y n$ in the SON} and PVN of Dp71-null mice

To determine whether the cellular locations of utrophins, $\beta-\mathrm{DG}$, and $\alpha 1-$ Syn were compatible with the formation of functional DAPCs in Dp71-null mice, we used immunohistochemistry (IHC) and the same antibodies we used for western blots to identify the precise locations of these proteins in the hypothalami of Dp71-null and wild-type mice.

Utrophins were detected in ventral glial limitans (VGLs) and around blood vessels in the SON and PVN of wild-type and Dp71-null mice (Fig. 2). In contrast to the similar levels of utrophins detected by western blotting, utrophin staining intensity was slightly higher in the VGL of Dp71-null mice than in those of wild-type mice but remained constant in the SON (SON: $100 \pm 4 \cdot 7$ for wild-type mice, $91 \cdot 7 \pm 7 \cdot 7$ for Dp71-null mice; and PVN: $100 \pm 8 \cdot 1$ for wild-type mice, $97 \cdot 8 \pm 6 \cdot 8$ for Dp71-null mice). Utrophin staining around blood vessels overlapped with that of GFAP, which suggests that utrophins are located in astrocyte end feet (Fig. 2). $\beta$-DG staining was found in the VGL and around blood vessels in the SON and PVN sections and its distribution was the same for Dp71-null and wild-type mice (SON: $100 \pm 6 \cdot 2$ for wild-type mice, $111 \cdot 8 \pm 11 \cdot 1$ for Dp71-null mice; and PVN: $100 \pm 8 \cdot 1$ for wild-type mice, $112 \cdot 1 \pm 7 \cdot 2$ for Dp71-null mice; Fig. 3). Colocalization of $\beta-D G$ staining with GFAP staining, and with CD31 staining, around SON blood vessels indicated that $\beta$-DG was present in the perivascular astrocyte end feet and in the endothelial cells (Fig. 3E and F). By contrast, dual staining for $\beta-D G$ and AVP, as a magnocellular neuron marker, demonstrated the absence of $\beta-D G$ in these neurons (Fig. 3G). We detected $\alpha 1-$ Syn staining in the SON and PVN of wild-type mice (Fig. 4A and C), but this staining was less intense in Dp71-null mice (SON: $100 \pm 4 \cdot 1$ for wild-type 
SON

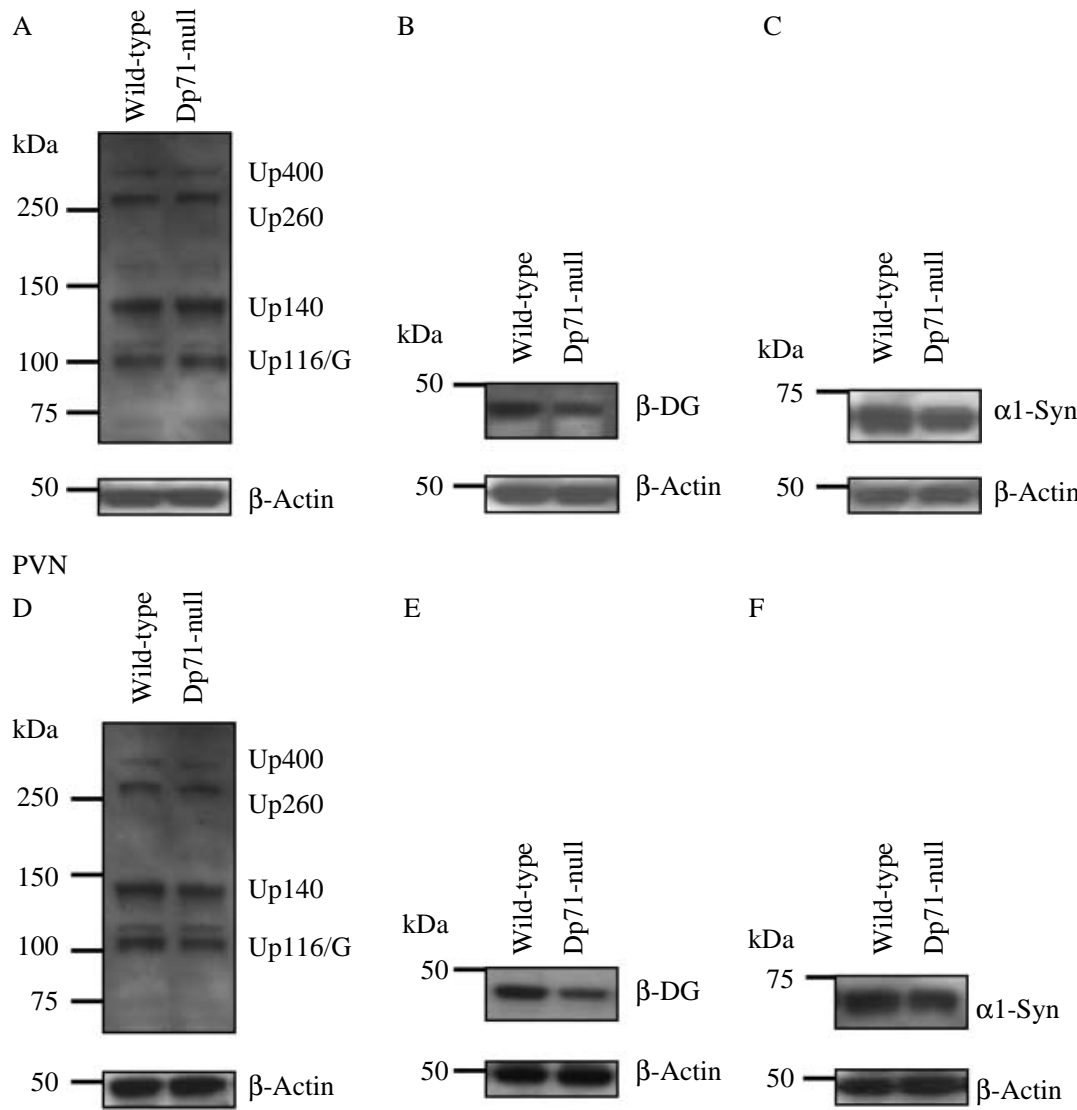

Figure 1 Expression of utrophins, $\beta$-DG, and $\alpha 1-S y n$ in the hypothalami of wild-type and Dp71-null mice. Proteins extracts from the SON and the PVN of wild-type and Dp71-null mice were analyzed by western blotting using antibodies against utrophin, $\beta$-DG, and $\alpha 1-S y n$. Four bands corresponding to the utrophin isoforms Up400, Up260, Up140, and Up116 were detected in both strains of mice (A and D). $\beta$-DG (B and E), and $\alpha 1$-Syn ( $C$ and F) were detected as single bands at 43 and 59 kDa respectively. The absence of DP71 did not affect the intensity of the utrophin bands. In Dp71-null mice, the band intensities of $\beta$-DG and $\alpha 1$-Syn were both comparatively lower than those of wild-type mice. Molecular weight markers are indicated on the left. $\beta$-Actin was used as a loading control.

mice, $43 \cdot 4 \pm 9 \cdot 2$ * for Dp71-null mice; and PVN: $100 \pm 9 \cdot 2$ for wild-type mice, $56 \cdot 5 \pm 7 \cdot 1$ * for Dp71-null mice, $P<0 \cdot 05$; Fig. $4 \mathrm{~B}$ and D). These results agreed with those of our western blot analysis. The colocalization of $\alpha 1-$ Syn staining with GFAP staining and with CD31 staining (Fig. 4E and F) around SON and PVN vessels demonstrated that $\alpha 1-$ Syn is expressed in perivascular astrocyte end feet and in endothelial cells. By contrast, $\alpha 1-S y n$ was not detected in AVP-positive/magnocellular neurons (Fig. 4G).

\section{Expression, distribution, and activity of $n N O S$ in the SON and} PVN of Dp71-null mice

We used nNOS protein levels in the SON and the PVN of DP71-null mice as an index of the osmoregulatory axis activation due to magnocellular neuron activity, and to assess DAPC functional output.

On immunoblots, nNOS was detected as a single band of $160 \mathrm{kDa}$ (Boissel et al. 1998). In SON and PVN extracts, the levels of nNOS were significantly higher in Dp7-1-null mice than in wild-type mice (Fig. 5A and $\mathrm{H}$ and Table 1). We also detected nNOS immunoreactivity in the magnocellular neuronal neurons of both SON and PVN (Fig. 5B and I). nNOS immunostaining intensity and the numbers of nNOS-immunopositive magnocellular neurons were both higher in the SON and PVN of Dp71-null mice than in those of wild-type mice (SON: $100 \pm 2 \cdot 3$ for wild-type mice, $175 \cdot 5 \pm 10 \cdot 3$ * for Dp71-null mice; and PVN: $100 \pm 4 \cdot 8$ for wild-type mice, $130 \cdot 9 \pm 3 \cdot 7 \star$ for Dp71-null mice, $P<0 \cdot 05$; Fig. 5E and L). 
Table 1 Effects of $D p 71$ gene disruption on the protein levels of utrophins, $\beta$-DG, $\alpha 1$-Syn, and nNOS. The levels of utrophins (Up400, Up260, Up140, and Up116/G), $\beta$-DG, $\alpha 1-S y n$, and nNOS in the SON and PVN of wild-type and Dp71-null mice are expressed in arbitrary units as the mean \pm s.E.M. $(n=4-5$ for each point). Each value represents the ratio of the staining intensity for the specific band normalized to that of a $\beta$-actin loading control

\begin{tabular}{|c|c|c|c|c|}
\hline \multirow[b]{2}{*}{ Protein/glycoprotein } & \multicolumn{2}{|l|}{ SON $^{\mathrm{a}}$} & \multicolumn{2}{|l|}{$\mathbf{P V N}^{\mathrm{a}}$} \\
\hline & Wild-type & DP-71 null & Wild-type & DP71-null \\
\hline \multicolumn{5}{|l|}{ Utrophin } \\
\hline Up400 & $8.93 \pm 0.53$ & $9 \cdot 30 \pm 0 \cdot 25$ & $9 \cdot 60 \pm 0 \cdot 81$ & $9 \cdot 15 \pm 0 \cdot 33$ \\
\hline Up260 & $16 \cdot 64 \pm 0 \cdot 72$ & $17 \cdot 83 \pm 0.97$ & $18 \cdot 10 \pm 1 \cdot 27$ & $17 \cdot 83 \pm 1 \cdot 02$ \\
\hline Up140 & $18 \cdot 31 \pm 1 \cdot 47$ & $17 \cdot 95 \pm 1 \cdot 00$ & $18 \cdot 06 \pm 0.62$ & $18 \cdot 45 \pm 0.67$ \\
\hline Up116/G & $11 \cdot 80 \pm 0 \cdot 82$ & $12 \cdot 12 \pm 1 \cdot 40$ & $14 \cdot 32 \pm 1 \cdot 17$ & $14 \cdot 81 \pm 0 \cdot 67$ \\
\hline$\beta$-DG & $22 \cdot 92 \pm 1 \cdot 01$ & $17 \cdot 81 \pm 0 \cdot 73^{*}$ & $23 \cdot 14 \pm 0 \cdot 75$ & $15 \cdot 65 \pm 0 \cdot 28^{*}$ \\
\hline$\alpha 1-S y n$ & $33 \cdot 55 \pm 0 \cdot 61$ & $28 \cdot 62 \pm 0.97^{*}$ & $28.93 \pm 1.93$ & $24 \cdot 81 \pm 1 \cdot 07^{*}$ \\
\hline nNOS & $16 \cdot 25 \pm 1 \cdot 21$ & $25 \cdot 14 \pm 1 \cdot 43^{*}$ & $17 \cdot 48 \pm 1 \cdot 43$ & $24 \cdot 09 \pm 2 \cdot 11^{*}$ \\
\hline
\end{tabular}

$* P<0 \cdot 05$ compared with control group by a one-way ANOVA.

${ }^{a}$ Band intensity relative to $\beta$-actin (arbitrary units).

In the brain, NADPH-diaphorase staining correlates with nNOS activity. We found NADPH-diaphorase staining to be localized in the magnocellular neurons of the SON and PVN (Fig. 5C and J). The numbers of NADPH-diaphorasepositive stained neurons and the intensity of NADPHdiaphorase staining per positive cell were both substantially higher in the SON and PVN of Dp71-null mice than in those of the wild-type mice (SON: $100 \pm 1 \cdot 5$ for wild-type mice, $127 \cdot 3 \pm 3 \cdot 2$ * for Dp71-null mice; and PVN: $100 \pm 3 \cdot 3$ for wild-type mice, $125 \cdot 1 \pm 1 \cdot 4$ ᄎ for Dp71-null mice, $P<0 \cdot 05$; Fig. $5 \mathrm{~F}$ and $\mathrm{M}$ ). This demonstrated that the higher levels of nNOS protein found in the Dp71-null mice were also accompanied by higher levels of nNOS activity.

Coimmunostaining of $\mathrm{nNOS}$ and dystrophin confirmed that dystrophin was absent from astrocyte end feet around the hypothalamic blood vessels of Dp71-null mice and that it was expressed in the magnocellular neurons (Fig. 5D, G, K and N). We previously reported that this staining corresponds to the DP140 isoform (Benabdesselam et al. 2010). nNOS staining was preferentially localized in some dystrophin-positive neurons located in the dorsal part of the SON and in the lateral part of the PVN (Fig. 5G and N).

\section{Discussion}

In a previous study, we showed that DP71 was the major dystrophin isoform in the SON and PVN of normal mice (Benabdesselam et al. 2010). DP71 was found in endothelial cells and in astrocyte end feet around vessels, where it probably participates in the osmosensitivity of the SON and PVN. When DP71 was absent, dystrophin exhibited a modified cellular distribution. Dystrophins disappeared completely from blood vessel areas but appeared in AVPpositive neurons as the DP140 isoform. These changes in dystrophin expression and distribution were accompanied in DP71-null mice by lower plasma osmolality, which persisted after osmotic stimulation. This result indicated that the 'set point' of the osmostat was altered in the absence of DP71. The absence of DP71 and the ectopic expression of DP140 could lead to modified signal integration in the hypothalamus that disturbs the fine-tuning of AVP expression. Since dystrophins exert their function through the multiprotein complex DAPC, we analyzed the consequences of DP71 disruption on the expression and distribution of the other members of the DAPC, $\beta-D G, \alpha 1-S y n$, and the utrophins, which are the autosomal homologs of dystrophins. nNOS expression and activity were also investigated as a functional index of the hypothalamo-neurohypophyseal axis activity and as the functional outputs of DAPC activity.

\section{Utrophins}

The SON and PVN of wild-type mice contain various utrophin isoforms: Up400, Up260, Up140, and Up116/G. As previously described, we found these proteins to be localized around vessels, notably in endothelial cells and in astrocyte end feet surrounding the vessels (Khurana et al. 1992, Blake et al. 1999, Knuesel et al. 2000, Haenggi et al. 2004). Like dystrophins, utrophins are attached to the cell membrane (Khurana et al. 1992) and are associated with the same proteins and glycoproteins as those associated with dystrophins (Matsumura et al. 1992). In the absence of dystrophin, utrophins are upregulated in skeletal muscle (Galvagni et al. 2002, Kleopa et al. 2006) and in the retina (Dalloz et al. 2001, 2003). A similar upregulation was not seen in the hypothalamus of Dp71-null mice since their utrophin levels did not change. This absence of compensatory utrophin upregulation in the Dp71-null mice, and the appearance of ectopic DP140 expression in AVP-positive neurons (Benabdesselam et al. 2010), may partially explain why these mice exhibit a modified osmoregulatory axis with a lower osmostat. 

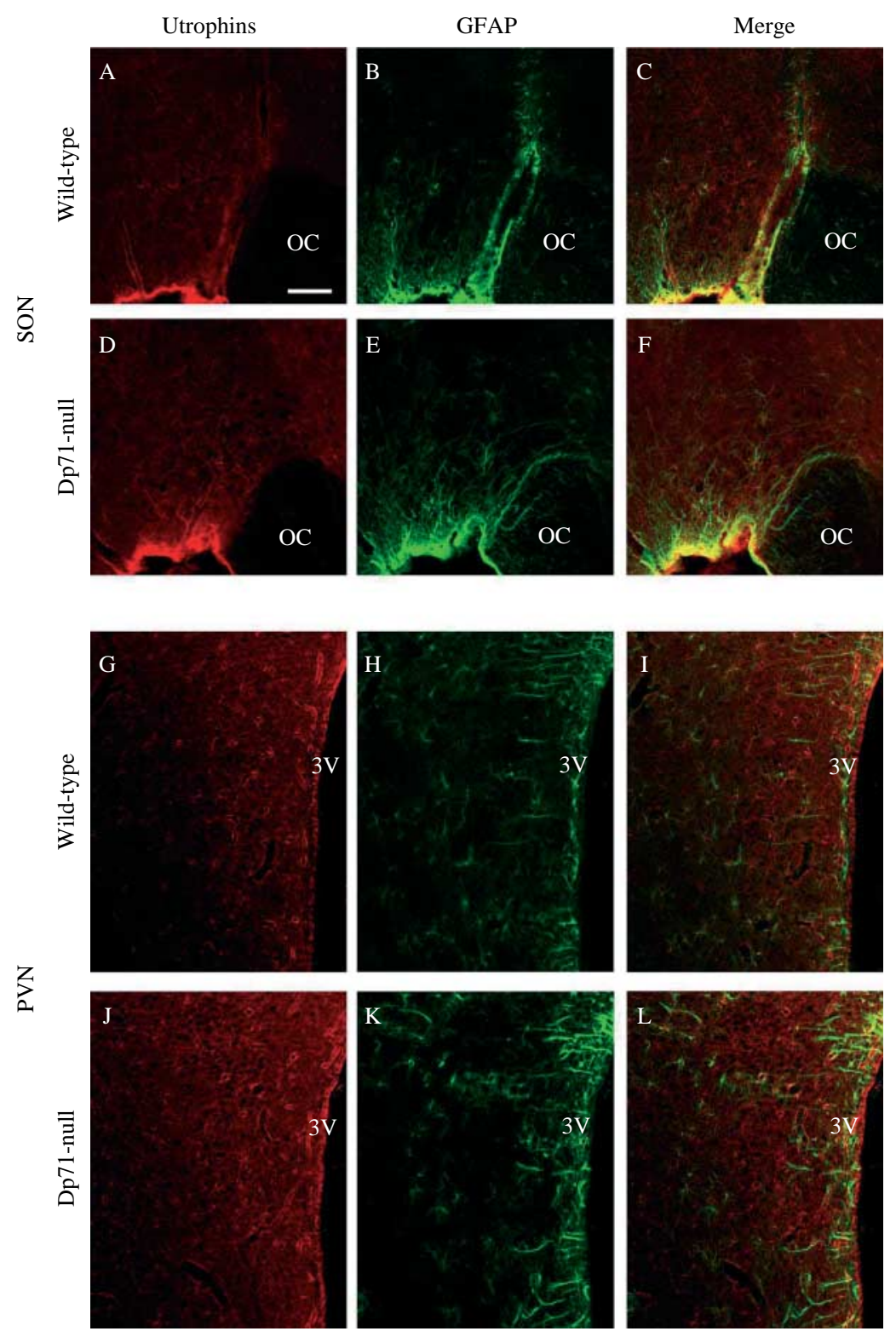

Figure 2 Effect of $D p 71$ gene disruption on utrophin distribution. Immunohistochemical detection of utrophins in the VGL and around blood vessels in the SON (A and D) and PVN (G and J) of wild-type and Dp71-null mice. Colocalization of utrophins with GFAP immunostaining in the SON (B, C, E and F) and in the PVN $(\mathrm{H}, \mathrm{I}, \mathrm{K}$ and $\mathrm{L})$ demonstrated that utrophins are present in astrocyte end feet. OC, optic chiasma; $3 \mathrm{~V}$, third ventricle. Scale bar: $60 \mu \mathrm{m}$.

\section{$\beta-D G$ and $\alpha 1-S y n$}

In the SON and PVN of wild-type mice, $\beta-\mathrm{DG}$ and $\alpha 1-\mathrm{Syn}$ were localized in endothelial cells and astrocyte end feet surrounding the blood vessels. This result is consistent with those of other studies that showed $\beta-D G$ is associated with $\alpha 1-$ Syn in the interface between glial cells and vessels of the brain (Tian et al. 1996, Blake et al. 1999, Haenggi \& Fritschy 2006). Indeed, in the SON and PVN of wild-type mice, the distributions of $\beta-D G$ and $\alpha 1-$ Syn are similar to those of the dystrophins and utrophins, suggesting that dystrophins and utrophins are in position in the astrocyte end feet to interact with $\beta-D G$ and $\alpha 1$-Syn and form functional DAPCs. 

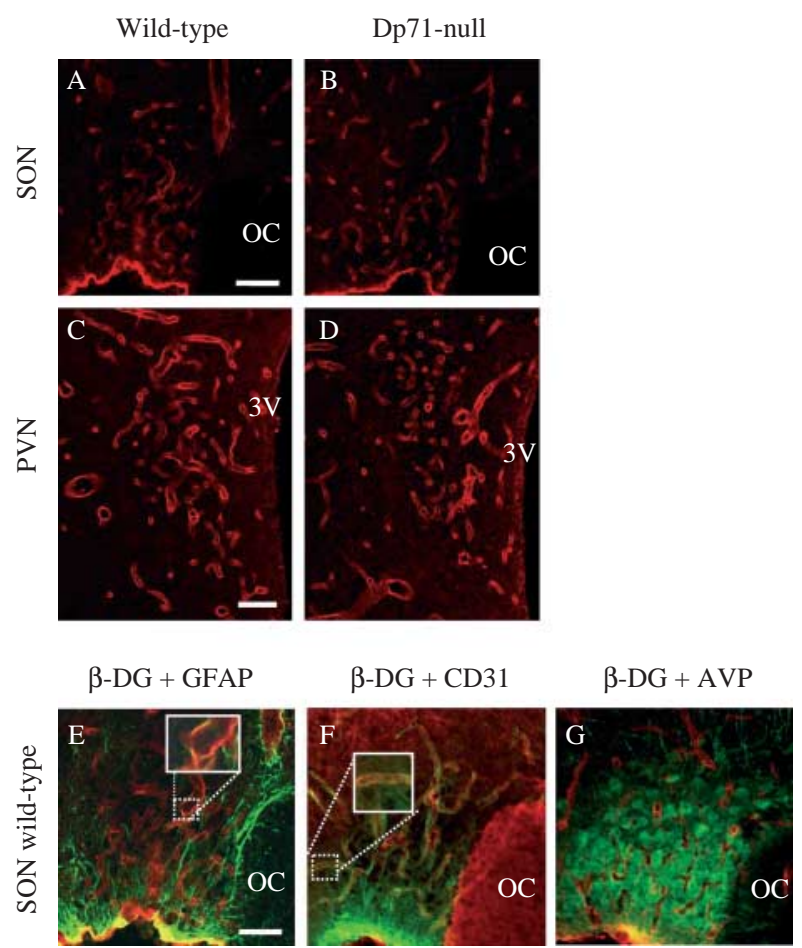

Figure 3 Effect of DP71 disruption on $\beta$-DG distribution. Immunohistochemical detection of $\beta$-DG in the SON (A and B) and PVN $(C$ and D) of wild-type and Dp71-null mice. $\beta$-DG was detected in the parenchyma and around blood vessels. Colocalization of $\beta$-DG with GFAP $(E), C D 31(F)$, and AVP $(G)$ in the SON of wild-type mice demonstrates that $\beta$-DG is present in astrocyte end feet and in endothelial cells but not in the magnocellular neurons. OC, optic chiasma; 3V, third ventricle. Scale bar: $60 \mu \mathrm{m}$.

In the SON and PVN of Dp71-null mice, the distribution of $\beta$-DG was not different from that in wild-type mice but the levels of $\beta$-DG were lower. This was also observed in the retina (Dalloz et al. 2003) and in olfactory cells of Dp71-null mice (Takatoh et al. 2008). These results demonstrate that in the hypothalamus, the localization of $\beta-\mathrm{DG}$ in astrocyte end feet is not exclusively dependent on the presence of DP71, but may involve utrophins and/or other unidentified proteins, as was previously proposed (Howard et al. 1998, Blank et al. 1999). The level of $\alpha 1-$ Syn was lower in both the SON and PVN of Dp71-null mice than in wild-type mice and almost completely absent from around vessels, suggesting that the DAPC in the astrocyte end feet of the Dp71-null mice contained utrophins and $\beta$-DG but not $\alpha 1$-Syn. DAPC, via dystroglycans and SYN, constitutes a transmembrane system that connects the intracellular cytoskeleton to the extracellular matrix (Tadayoni et al. 2012). Modification of the DAPC composition may thus have several consequences. First, it may affect cell morphology and cellular extensions, as has been described for astrocyte end feet (Noell et al. 2011). This could thus explain the morphological changes in the astrocytic processes that we previously described in these areas (Benabdesselam et al. 2010). Modification in the DAPC composition also perturbs the abilities of cells to integrate signals coming from the microenvironment, as has been demonstrated for the blood-brain barrier (Eilert-Olsen et al. 2012). Since endothelial cells and astrocyte end feet in the SON and PVN are associated with physiological osmoreception (Bourque 2008), modified DAPCs in these cells could perturb the detection of plasmatic osmolality and/ or the transduction of necessary signals, which could thus explain why the osmostat of the Dp71-null mice is impaired.

\section{$n N O S$ expression and activity}

Next to their osmoreceptive function, the SON and PVN have a major role as the effector pole in osmoregulation as they adapt the synthesis and release of AVP to variations in plasmatic osmolality. These functions are fine-tuned by magnocellular activity, and among the different modulatory pathways, the NO pathway is particularly important (Antunes-Rodrigues et al. 2004, Grange-Messent et al. 2004, Maolood et al. 2007). nNOS is expressed at high levels in the SON and PVN (Sagar \& Ferriero 1987, Pasqualotto et al. 1991, Arévalo et al. 1992, Vincent \& Kimura 1992) and its expression is functionally regulated by osmotic stimulation
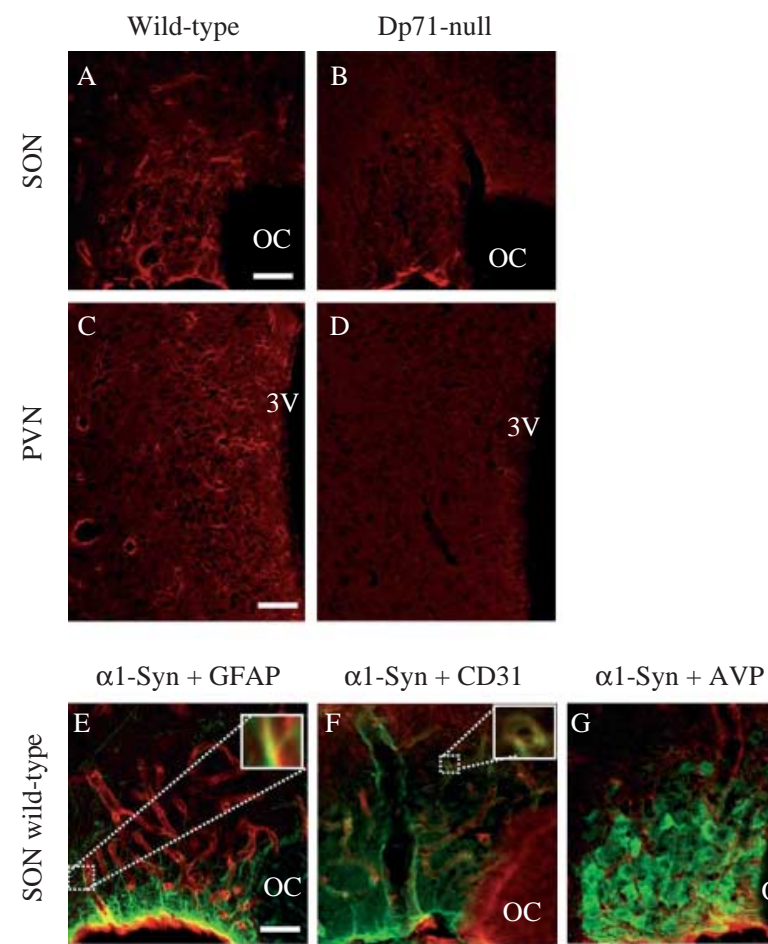

Figure 4 Effect of $D p 71$ gene disruption on $\alpha 1$-Syn distribution. Immunohistochemical detection of $\alpha 1-$ Syn in the SON (A and B) and PVN (C and D) of wild-type and Dp71-null mice. $\alpha 1$-Syn was detected in the parenchyma and around blood vessels. Colocalization of $\alpha 1$-Syn with GFAP (E), CD31 (F), and AVP (G) in the SON of wild-type mice demonstrates that $\alpha 1$-Syn is present in astrocyte end feet and in endothelial cells but not in the magnocellular neurons. OC, optic chiasma; 3V, third ventricle. Scale bar: $60 \mu \mathrm{m}$. 

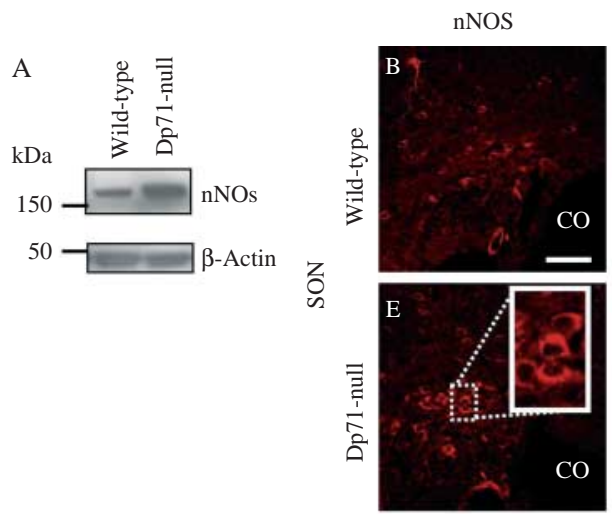

NADPH-diaphorase

$\mathrm{nNOS}+\mathrm{Dp}$
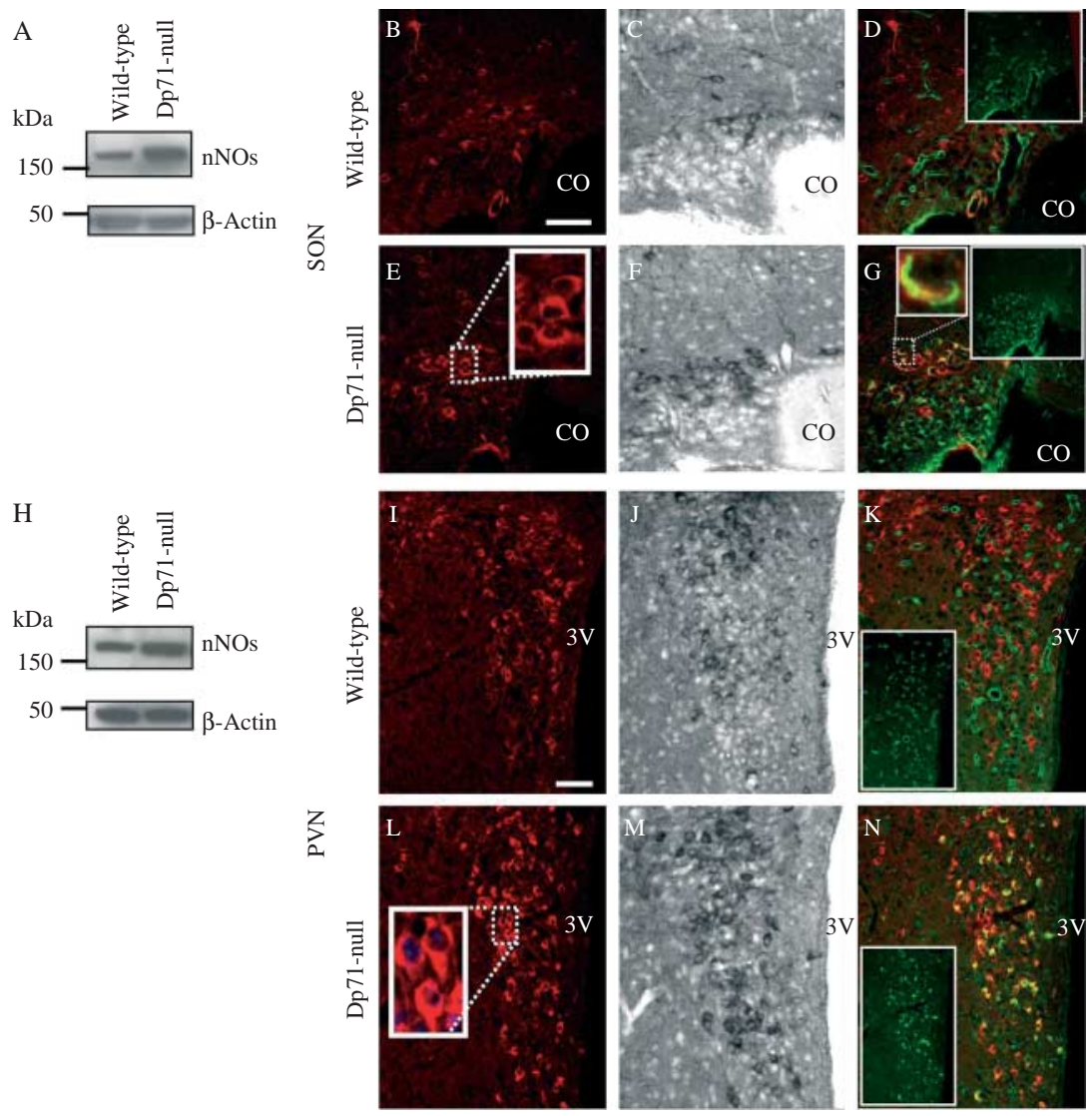

Figure 5 Effect of $D p 71$ gene disruption on nNOS expression and activity. Proteins extracts from the SON (A) and the PVN (H) of wild-type and Dp71-null mice were analyzed by western blotting using antibodies against nNOS, which was detected as a single band of $160 \mathrm{kDa}$. In the absence of DP71, nNOS levels were higher in both in the SON and the PVN. nNOS was localized by IHC in the SON (B and E) and PVN (I and L) of wild-type and Dp71null mice and its activity was detected using NAPDH-diaphorase histochemistry (C, F, J and M). $\mathrm{nNOS}$ was detected in magnocellular neurons and its expression and activity were higher in the absence of DP71 than in the magnocellular neurons of wild-type mice. Colocalization of nNOS with dystrophins (Dp; D, G, K and N) demonstrates that nNOS is expressed in dystrophin-positive neurons in Dp71-null mice. OC, optic chiasma; 3V, third ventricle. Scale bar: $60 \mu \mathrm{m}$.

(Kadowaki et al. 1994, Villar et al. 1994, Ueta et al. 1998). Because nNOS may be functionally related to DAPC (Tadayoni et al. 2012), we analyzed its expression and activity after DP71 disruption.

In wild-type mice, we confirmed previous reports of nNOS in the magnocellular neurons located in the dorsal part of the SON and in the lateral part of the PVN (Vacher et al. 2003, Maolood et al. 2007). nNOS expression was higher in the SON and PVN of Dp71-null mice, which is similar to what has been reported to occur in response to osmotic stimulation (Kadowaki et al. 1994), hypovolemia (Ueta et al. 1998), and noradrenalin treatment (Grange-Messent et al. 2004, Maolood et al. 2007). Similarly, NADPH-diaphorase staining was higher in both the SON and PVN of Dp71-null mice. Since NADPH-diaphorase activity correlates with the distribution and activity of nNOS in the rodent brain (Bredt et al. 1991, Warembourg et al. 1999), this suggests that elevated nNOS expression was accompanied by higher nNOS activity and higher levels of NO production. Such a modified NO pathway could also partially explain the altered osmolar status of the Dp71-null mice (Benabdesselam et al. 2010).

In hypothalamic sections of the adult rat, nNOS and $\alpha 1-$ Syn were found to be highly expressed and colocalized in the neurons of the suprachiasmatic nuclei (Hashida-Okumura et al. 1999). In others tissues, such as skeletal muscle, nNOS is targeted to the sarcolemmal membrane by its association with SYN (Brenman et al. 1996) and this interaction is essential for its dimerization and thus its activity (Zhou \& Zhu 2009). This is not the case in the SON and PVN of the normal mice, since the cellular distribution of nNOS and $\alpha 1-$ Syn was not 
superimposed. These results suggest that other mechanisms, independent of the DAPC, anchor nNOS to cell membranes in the hypothalamus. For example, the PDZ motif in the $\mathrm{N}$-terminal domain of nNOS has been reported to interact with the PDZ motifs of different adapter proteins, such as PSD-95, PSD-93, and CAPON, which facilitate nNOS dimerization and form membrane-associated macromolecular complexes (Brenman et al. 1996, Jaffrey et al. 2002). In Dp71null mice, the higher levels of nNOS expression and activity correlated with the emergence of DP140 in the magnocellular neurons. However, since the other partners of the DAPC were absent from these neurons, the physical link between DP140 and nNOS remains to be determined.

In conclusion, our data demonstrate that in the SON and PVN of wild-type mice, the DAPC contains at least dystrophins, utrophins, $\beta-\mathrm{DG}$, and $\alpha 1-$ Syn. These different partners of the DAPC are absent in the magnocellular neurons and the complex is localized in astrocyte end feet, where it is in position to integrate the plasmatic osmolality information.

In the absence of DP71, de novo DP140 expression appeared in the magnocellular neurons but the other required components of the DAPC were poorly expressed. Thus, the function of this ectopic DP140 expression is unknown. $D p 71$ gene disruption reduced $\beta-D G$ and $\alpha 1-$ Syn synthesis in astrocyte end feet, which led to altered structural and neurochemical connections between the different cells of the SON and PVN and to a disturbance in the fine-tuning of magnocellular neuron activation.

\section{Declaration of interest}

The authors declare that there is no conflict of interest that could be perceived as prejudicing the impartiality of the research reported.

\section{Funding}

This work was supported by UPMC and CNRS.

\section{Acknowledgements}

We are grateful to R Benard for his contribution by Dp71-null mice breeding.

\section{References}

Adams ME, Kramarcy N, Krall SP, Rossi SG, Rotundo RL, Sealock R \& Froehner SC 2000 Absence of alpha-syntrophin leads to structurally aberrant neuromuscular synapses deficient in utrophin. Journal of Cell Biology 150 1385-1398. (doi:10.1083/jcb.150.6.1385)

Antunes-Rodrigues J, de Castro M, Elias LLK, Valença MM \& McCann SM 2004 Neuroendocrine control of body fluid metabolism. Physiological Reviews 84 169-208. (doi:10.1152/physrev.00017.2003)

Arévalo R, Sánchez F, Alonso JR, Carretero J, Vázquez R \& Aijón J 1992 NADPH-diaphorase activity in the hypothalamic magnocellular neurosecretory nuclei of the rat. Brain Research Bulletin 28 599-603. (doi:10. 1016/0361-9230(92)90109-B)
Benabdesselam R, Sene A, Raison D, Benmessaoud-Mesbah O, Ayad G, Mornet D, Yaffe D, Rendon A, Hardin-Pouzet H \& Dorbani-Mamine L 2010 A deficit of brain dystrophin 71 impairs hypothalamic osmostat. Journal of Neuroscience Research 88 324-334. (doi:10.1002/jnr.22198)

Blake DJ, Hawkes R, Benson MA \& Beesley PW 1999 Different dystrophinlike complexes are expressed in neurons and glia. Journal of Cell Biology 147 645-658. (doi:10.1083/jcb.147.3.645)

Blake DJ, Weir A, Newey SE \& Davies KE 2002 Function and genetics of dystrophin and dystrophin-related proteins in muscle. Physiological Reviews 82 291-329.

Blank M, Koulen P, Blake DJ \& Kröger S 1999 Dystrophin and betadystroglycan in photoreceptor terminals from normal and $\mathrm{mdx} 3 \mathrm{cv}$ mouse retinae. European Journal of Neuroscience 11 2121-2133. (doi:10.1046/j. 1460-9568.1999.00636.x)

Boissel JP, Schwarz PM \& Förstermann U 1998 Neuronal-type no synthase: transcript diversity and expressional regulation. Nitric Oxide 2 337-349. (doi:10.1006/niox.1998.0189)

Bourque CW 2008 Central mechanisms of osmosensation and systemic osmoregulation. Nature Reviews. Neuroscience 9 519-531. (doi:10.1038/ nrn2400)

Bredt DS, Glatt CE, Hwang PM, Fotuhi M, Dawson TM \& Snyder SH 1991 Nitric oxide synthase protein and mrna are discretely localized in neuronal populations of the mammalian CNS together with NADPH diaphorase. Neuron 7 615-624. (doi:10.1016/0896-6273(91)90374-9)

Brenman JE, Chao DS, Gee SH, McGee AW, Craven SE, Santillano DR, Wu Z, Huang F, Xia H, Peters MF et al. 1996 Interaction of nitric oxide synthase with the postsynaptic density protein psd-95 and alpha1syntrophin mediated by PDZ domains. Cell 84 757-767. (doi:10.1016/ S0092-8674(00)81053-3)

Claudepierre T, Rodius F, Frasson M, Fontaine V, Picaud S, Dreyfus H, Mornet D \& Rendon A 1999 Differential distribution of dystrophins in rat retina. Investigative Ophthalmology \& Visual Science 40 1520-1529.

Dalloz C, Claudepierre T, Rodius F, Mornet D, Sahel J \& Rendon A 2001 Differential distribution of the members of the dystrophin glycoprotein complex in mouse retina: effect of the $\operatorname{mdx}(3 \mathrm{cv})$ mutation. Molecular and Cellular Neurosciences 17 908-920. (doi:10.1006/mcne.2001.0978)

Dalloz C, Sarig R, Fort P, Yaffe D, Bordais A, Pannicke T, Grosche J, Mornet D, Reichenbach A, Sahel J et al. 2003 Targeted inactivation of dystrophin gene product dp71: phenotypic impact in mouse retina. Human Molecular Genetics 12 1543-1554. (doi:10.1093/hmg/ddg170) Eilert-Olsen M, Haj-Yasein NN, Vindedal GF, Enger R, Gundersen GA, Hoddevik EH, Petersen PH, Haug FS, Skare O, Adams ME et al. 2012 Deletion of aquaporin-4 changes the perivascular glial protein scaffold without disrupting the brain endothelial barrier. Glia $60432-440$. (doi:10.1002/glia.22277)

Galvagni F, Cantini M \& Oliviero S 2002 The utrophin gene is transcriptionally up-regulated in regenerating muscle. Journal of Biological Chemistry 277 19106-19113. (doi:10.1074/jbc.M109642200)

Grange-Messent V, Raison D, Dugas B \& Calas A 2004 Noradrenaline up-regulates the neuronal and the inducible nitric oxide synthase isoforms in magnocellular neurons of rat brain slices. Journal of Neuroscience Research 78 683-690. (doi:10.1002/jnr.20331)

Haenggi T \& Fritschy J 2006 Role of dystrophin and utrophin for assembly and function of the dystrophin glycoprotein complex in non-muscle tissue. Cellular and Molecular Life Sciences 63 1614-1631. (doi:10.1007/s00018-005-5461-0)

Haenggi T, Soontornmalai A, Schaub MC \& Fritschy J 2004 The role of utrophin and dp71 for assembly of different dystrophin-associated protein complexes (DPCs) in the choroid plexus and microvasculature of the brain. Neuroscience 129 403-413. (doi:10.1016/j.neuroscience.2004.06.079)

Hashida-Okumura A, Okumura N, Iwamatsu A, Buijs RM, Romijn HJ \& Nagai K 1999 Interaction of neuronal nitric-oxide synthase with alpha1syntrophin in rat brain. Journal of Biological Chemistry 274 11736-11741. (doi:10.1074/jbc.274.17.11736)

Howard PL, Dally GY, Wong MH, Ho A, Weleber RG, Pillers DA \& Ray PN 1998 Localization of dystrophin isoform dp71 to the inner limiting membrane of the retina suggests a unique functional contribution of dp 71 in the retina. Human Molecular Genetics 7 1385-1391. (doi:10.1093/hmg/7. 9.1385) 
Jaffrey SR, Benfenati F, Snowman AM, Czernik AJ \& Snyder SH 2002 Neuronal nitric-oxide synthase localization mediated by a ternary complex with synapsin and capon. PNAS 99 3199-3204. (doi:10.1073/pnas. 261705799)

Kadekaro M 2004 Nitric oxide modulation of the hypothalamo-neurohypophyseal system. Brazilian Journal of Medical and Biological Research 37 441-450. (doi:10.1590/S0100-879X2004000400001)

Kadowaki K, Kishimoto J, Leng G \& Emson PC 1994 Up-regulation of nitric oxide synthase (NOS) gene expression together with nos activity in the rat hypothalamo-hypophysial system after chronic salt loading: evidence of a neuromodulatory role of nitric oxide in arginine vasopressin and oxytocin secretion. Endocrinology 134 1011-1017. (doi:10.1210/en.134.3.1011)

Khurana TS, Watkins SC \& Kunkel LM 1992 The subcellular distribution of chromosome 6-encoded dystrophin-related protein in the brain. Journal of Cell Biology 119 357-366. (doi:10.1083/jcb.119.2.357)

Kleopa KA, Drousiotou A, Mavrikiou E, Ormiston A \& Kyriakides T 2006 Naturally occurring utrophin correlates with disease severity in duchenne muscular dystrophy. Human Molecular Genetics 15 1623-1628. (doi:10.1093/ hmg/ddl083)

Knuesel I, Bornhauser BC, Zuellig RA, Heller F, Schaub MC \& Fritschy JM 2000 Differential expression of utrophin and dystrophin in CNS neurons: an in situ hybridization and immunohistochemical study. Journal of Comparative Neurology 422 594-611. (doi:10.1002/10969861(20000710)422:4 < 594::AID-CNE8 > 3.0.CO;2-Q)

Koenig M, Monaco AP \& Kunkel LM 1988 The complete sequence of dystrophin predicts a rod-shaped cytoskeletal protein. Cell 53 219-228. (doi:10.1016/0092-8674(88)90383-2)

Kramarcy NR, Vidal A, Froehner SC \& Sealock R 1994 Association of utrophin and multiple dystrophin short forms with the mammalian $\mathrm{m}(\mathrm{r})$ 58,000 dystrophin-associated protein (syntrophin). Journal of Biological Chemistry 269 2870-2876.

Lai Y, Thomas GD, Yue Y, Yang HT, Li D, Long C, Judge L, Bostick B, Chamberlain JS, Terjung RL et al. 2009 Dystrophins carrying spectrin-like repeats 16 and 17 anchor nNOS to the sarcolemma and enhance exercise performance in a mouse model of muscular dystrophy. Journal of Clinical Investigation 119 624-635. (doi:10.1172/JCI36612)

Lapidos KA, Kakkar R \& McNally EM 2004 The dystrophin glycoprotein complex: signaling strength and integrity for the sarcolemma. Circulation Research 94 1023-1031. (doi:10.1161/01.RES.0000126574. 61061.25)

Maolood N, Grange-Messent V, Raison D \& Hardin-Pouzet H 2007 Noradrenergic regulation in mouse supraoptic nucleus involves a nitric oxide pathway only to regulate arginine-vasopressin expression and not oxytocin expression. Journal of Neuroscience Research 85 2991-2999. (doi:10.1002/jnr.21394)

Matsumura K, Ervasti JM, Ohlendieck K, Kahl SD \& Campbell KP 1992 Association of dystrophin-related protein with dystrophin-associated proteins in mdx mouse muscle. Nature 360 588-591. (doi:10.1038/ 360588a)

Matsumura K, Shasby DM \& Campbell KP 1993 Purification of dystrophinrelated protein (utrophin) from lung and its identification in pulmonary artery endothelial cells. FEBS Letters 326 289-293. (doi:10.1016/00145793(93)81810-M)

Michele DE \& Campbell KP 2003 Dystrophin-glycoprotein complex: post-translational processing and dystroglycan function. Journal of Biological Chemistry 278 15457-15460. (doi:10.1074/jbc. R200031200)

Noell S, Wolburg-Buchholz K, Mack AF, Beedle AM, Satz JS, Campbell KP, Wolburg H \& Fallier-Becker P 2011 Evidence for a role of dystroglycan regulating the membrane architecture of astroglial endfeet. European Journal of Neuroscience 33 2179-2186. (doi:10.1111/j.1460-9568.2011.07688.x)

Ohlendieck K, Matsumura K, Ionasescu VV, Towbin JA, Bosch EP, Weinstein SL, Sernett SW \& Campbell KP 1993 Duchenne muscular dystrophy: deficiency of dystrophin-associated proteins in the sarcolemma. Neurology 43 795-800.

Pasqualotto BA, Hope BT \& Vincent SR 1991 Citrulline in the rat brain: immunohistochemistry and coexistence with NADPH-diaphorase. Neuroscience Letters 128 155-160. (doi:10.1016/0304-3940(91)90250-W)
Piluso G, Mirabella M, Ricci E, Belsito A, Abbondanza C, Servidei S, Puca AA, Tonali P, Puca GA \& Nigro V 2000 Gamma1- and gamma2syntrophins, two novel dystrophin-binding proteins localized in neuronal cells. Journal of Biological Chemistry 275 15851-15860. (doi:10.1074/jbc M000439200)

Porter JD, Rafael JA, Ragusa RJ, Brueckner JK, Trickett JI \& Davies KE 1998 The sparing of extraocular muscle in dystrophinopathy is lost in mice lacking utrophin and dystrophin. Journal of Cell Science 111 (Pt 1) 1801-1811.

Raison D, Hardin-Pouzet H \& Grange-Messent V 2011 Differential involvement of noradrenaline and nitric oxide in the regulation of vasopressin and oxytocin expression in rat supraoptic nucleus. Journal of Neuroscience Research 89 764-772. (doi:10.1002/jnr.22568)

Rivier F, Robert A, Hugon G, Bonet-Kerrache A, Nigro V, Fehrentz JA, Martinez J \& Mornet D 1999 Dystrophin and utrophin complexed with different associated proteins in cardiac purkinje fibres. Histochemical Journal 31 425-432. (doi:10.1023/A:1003805905456)

Robert FR, Léon-Henri BP, Chapleur-Chateau MM, Girr MN \& Burlet AJ 1985 Comparison of three immunoassays in the screening and characterization of monoclonal antibodies against arginine-vasopressin. Journal of Neuroimmunology 9 205-220. (doi:10.1016/S0165-5728(85)80019-9)

Royuela M, Chazalette D, Hugon G, Paniagua R, Guerlavais V, Fehrentz JA, Martinez J, Labbe JP, Rivier F \& Mornet D 2003 Formation of multiple complexes between beta-dystroglycan and dystrophin family products. Journal of Muscle Research and Cell Motility 24 387-397. (doi:10.1023/ A:1027309822007)

Rybakova IN, Patel JR, Davies KE, Yurchenco PD \& Ervasti JM 2002 Utrophin binds laterally along actin filaments and can couple costameric actin with sarcolemma when overexpressed in dystrophindeficient muscle. Molecular Biology of the Cell 13 1512-1521. (doi:10.1091/ mbc.01-09-0446)

Sagar SM \& Ferriero DM 1987 NADPH diaphorase activity in the posterior pituitary: relation to neuronal function. Brain Research 400 348-352. (doi:10.1016/0006-8993(87)90633-0)

Sarig R, Mezger-Lallemand V, Gitelman I, Davis C, Fuchs O, Yaffe D \& Nudel U 1999 Targeted inactivation of dp71, the major non-muscle product of the dmd gene: differential activity of the dp71 promoter during development. Human Molecular Genetics 8 1-10. (doi:10.1093/hmg/8.1.1)

Scherer-Singler U, Vincent SR, Kimura H \& McGeer EG 1983 Demonstration of a unique population of neurons with NADPHdiaphorase histochemistry. Journal of Neuroscience Methods 9 229-234. (doi:10.1016/0165-0270(83)90085-7)

Sgambato A \& Brancaccio A 2005 The dystroglycan complex: from biology to cancer. Journal of Cellular Physiology 205 163-169. (doi:10.1002/jcp.20411)

St-Louis R, Parmentier C, Raison D, Grange-Messent V \& Hardin-Pouzet H 2012 Reactive oxygen species are required for the hypothalamic osmoregulatory response. Endocrinology 153 1317-1329. (doi:10.1210/en. 2011-1350)

Suzuki A, Yoshida M, Hayashi K, Mizuno Y, Hagiwara Y \& Ozawa E 1994 Molecular organization at the glycoprotein-complex-binding site of dystrophin. three dystrophin-associated proteins bind directly to the carboxy-terminal portion of dystrophin. European Journal of Biochemistry 220 283-292. (doi:10.1111/j.1432-1033.1994.tb18624.x)

Tadayoni R, Rendon A, Soria-Jasso LE \& Cisneros B 2012 Dystrophin dp71: the smallest but multifunctional product of the duchenne muscular dystrophy gene. Molecular Neurobiology 45 43-60. (doi:10.1007/s12035011-8218-9)

Takatoh J, Kudoh H, Kondo S \& Hanaoka K 2008 Loss of short dystrophin isoform dp71 in olfactory ensheathing cells causes vomeronasal nerve defasciculation in mouse olfactory system. Experimental Neurology 213 36-47. (doi:10.1016/j.expneurol.2008.04.041)

Thomas GD, Sander M, Lau KS, Huang PL, Stull JT \& Victor RG 1998 Impaired metabolic modulation of alpha-adrenergic vasoconstriction in dystrophin-deficient skeletal muscle. PNAS 95 15090-15095. (doi:10.1073/pnas.95.25.15090)

Thomas GD, Shaul PW, Yuhanna IS, Froehner SC \& Adams ME 2003 Vasomodulation by skeletal muscle-derived nitric oxide requires 
alpha-syntrophin-mediated sarcolemmal localization of neuronal nitric oxide synthase. Circulation Research 92 554-560. (doi:10.1161/01.RES. 0000061570.83105.52)

Tian M, Jacobson C, Gee SH, Campbell KP, Carbonetto S \& Jucker M 1996 Dystroglycan in the cerebellum is a laminin alpha 2-chain binding protein at the glial-vascular interface and is expressed in purkinje cells. European Journal of Neuroscience 8 2739-2747. (doi:10.1111/j.1460-9568.1996.tb01568.x)

Tinsley JM, Blake DJ, Roche A, Fairbrother U, Riss J, Byth BC, Knight AE, Kendrick-Jones J, Suthers GK, Love DR et al. 1992 Primary structure of dystrophin-related protein. Nature 360 591-593. (doi:10.1038/360591a0)

Tinsley JM, Blake DJ, Zuellig RA \& Davies KE 1994 Increasing complexity of the dystrophin-associated protein complex. PNAS $918307-8313$. (doi:10.1073/pnas.91.18.8307)

Ueta Y, Levy A, Chowdrey HS \& Lightman SL 1995 Water deprivation in the rat induces nitric oxide synthase (NOS) gene expression in the hypothalamic paraventricular and supraoptic nuclei. Neuroscience Research 23 317-319. (doi:10.1016/0168-0102(95)00956-6)

Ueta Y, Levy A, Lightman SL, Hara Y, Serino R, Nomura M, Shibuya I, Hattori Y \& Yamashita H 1998 Hypovolemia upregulates the expression of neuronal nitric oxide synthase gene in the paraventricular and supraoptic nuclei of rats. Brain Research 790 25-32. (doi:10.1016/S0006-8993(97)01531-X)

Vacher CM, Hardin-Pouzet H, Steinbusch HWM, Calas A \& De Vente J 2003 The effects of nitric oxide on magnocellular neurons could involve multiple indirect cyclic GMP-dependent pathways. European Journal of Neuroscience 17 455-466. (doi:10.1046/j.1460-9568.2003.02467.x)

Villar MJ, Ceccatelli S, Rönnqvist M \& Hökfelt T 1994 Nitric oxide synthase increases in hypothalamic magnocellular neurons after salt loading in the rat. an immunohistochemical and in situ hybridization study. Brain Research 644 273-281. (doi:10.1016/0006-8993(94)91690-X)
Vincent SR \& Kimura H 1992 Histochemical mapping of nitric oxide synthase in the rat brain. Neuroscience 46 755-784. (doi:10.1016/03064522(92)90184-4)

Warembourg M, Leroy D \& Jolivet A 1999 Nitric oxide synthase in the guinea pig preoptic area and hypothalamus: distribution, effect of estrogen, and colocalization with progesterone receptor. Journal of Comparative Neurology 407 207-227. (doi:10.1002/(SICI)1096-9861(19990503)407:2<

207::AID-CNE5 $>$ 3.0.CO;2-A)

Winder SJ 2001 The complexities of dystroglycan. Trends in Biochemical Sciences 26 118-124. (doi:10.1016/S0968-0004(00)01731-X)

Winder SJ, Hemmings L, Maciver SK, Bolton SJ, Tinsley JM, Davies KE, Critchley DR \& Kendrick-Jones J 1995 Utrophin actin binding domain: analysis of actin binding and cellular targeting. Journal of Cell Science $\mathbf{1 0 8}$ (Pt 1) 63-71.

Yuan Q, Scott DE, So K \& Wu W 2006 Developmental changes of nitric oxide synthase expression in the rat hypothalamoneurohypophyseal system. Anatomical Record. Part A, Discoveries in Molecular, Cellular, and Evolutionary Biology 288 36-45. (doi:10.1002/ar.a.20271)

Zhou L \& Zhu D 2009 Neuronal nitric oxide synthase: structure, subcellular localization, regulation, and clinical implications. Nitric Oxide 20 223-230. (doi:10.1016/j.niox.2009.03.001)

Received in final form 22 March 2012

Accepted 5 April 2012

Made available online as an Accepted Preprint 5 April 2012 